\title{
Volumes Anestésicos Efetivos no Bloqueio do Nervo Isquiático: Comparação entre as Abordagens Parassacral e Infraglútea- Parabiceptal com Bupivacaína a 0,5\% com Adrenalina e Ropivacaína a 0,5\% *
}

\section{Effective Anesthetic Volumes In Sciatic Nerve Block: Comparison between the Parasacral and Infragluteal-parabiceps Approaches with 0.5\% Bupivacaine with Adrenaline and 0.5\% Ropivacaine*}

\author{
Pablo Escovedo Helayel, TSA ${ }^{1}$, Diogo Brüggemann da Conceição, TSA ${ }^{2}$, Julian Alexander Knaesel ${ }^{3}$,
} Maurício Sperotto Ceccon ${ }^{3}$, Adilson José Dal Mago, TSA ${ }^{4}$, Getúlio Rodrigues de Oliveira Filho, TSA ${ }^{5}$

\begin{abstract}
RESUMO
Helayel PE, Conceição DB, Knaesel JA, Ceccon MS, Dal Mago AJ, Oliveira Filho GR - Volumes Anestésicos Efetivos no Bloqueio do Nervo Isquiático: Comparação entre as Abordagens Parassacral e Infraglútea-Parabiceptal com Bupivacaína a 0,5\% com Adrenalina e Ropivacaína a 0,5\%.
\end{abstract}

JUSTIFICATIVA E OBJETIVOS: O volume e a massa das soluções de anestésico local (AL) influenciam a taxa de sucesso dos bloqueios periféricos. Desta forma, o objetivo principal do estudo foi determinar os volumes de anestésico local para o bloqueio do nervo isquiático (BNI) nas abordagens parassacral e infraglútea-parabiceptal.

MÉTODO: Cento e um pacientes foram alocados aleatoriamente em 4 grupos e submetidos ao BNI nas abordagens infraglútea-parabiceptal ou parassacral, utilizando ropivacaína a 0,5\% ou bupivacaína a 0,5\% com adrenalina $5 \mu \mathrm{g} \cdot \mathrm{mL}^{-1}$. Sucesso foi definido como bloqueio sensitivo e motor completo do nervo isquiático 30 minutos após a injeção do AL. Os volumes foram calculados pelo método upand-down

RESULTADOS: Na abordagem parassacral o volume efetivo médio da ropivacaína foi 17,6 mL (IC 95\%: 14,9 - 20,8) e da bupivacaína 16,4 mL (IC $95 \%: 12,3$ - 21,9). Na abordagem infraglútea-parabiceptal o volume efetivo médio da ropivacaína foi 21,8 mL (IC 95\%: 18,7 - 25,5) e bupivacaína 20,4 $m L$ (IC 95\%: 18,6 - 22,5). Volumes foram significativamente menores $(p<0,01)$ na abordagem parassacral comparativamente à infraglútea-parabiceptal. $\mathrm{Na}$ estimativa da regressão de Probits para volumes efetivos em 95\% dos paci-

\footnotetext{
* Recebido do Hospital Governador Celso Ramos - CET/SBA Integrado de Anestesiologia da Secretaria de Estado da Saúde de Santa Catarina (SESSC) e Núcleo de Ensino e Pesquisa em Anestesia Regional (NEPAR), Florianópolis, SC

1. Anestesiologista; Instrutor Corresponsável do CET e Coordenador e Pesquisador do NEPAR do CET/SBA Integrado de Anestesiologia da SES-SC 2. Anestesiologista; Pesquisador do NEPAR do CET/SBA Integrado de Anestesiologia da SES-SC.

3. ME do CET/SBA Integrado de Anestesiologia da SES-SC

4. Anestesiologista; Instrutor Corresponsável do CET e Pesquisador do NEPAR do CET/SBA Integrado de Anestesiologia da SES-SC

5. Anestesiologista; Doutor em Anestesiologia; Responsável do CET e Pesquisador do NEPAR do CET/SBA Integrado de Anestesiologia da SES-SC
}

Apresentado (Submitted) em 18 de julho de 2008

Aceito (Accepted) para publicação em 12 de junho de 2009

Endereço para correspondência (Correspondence to):

Dr. Pablo Escovedo Helayel

Av. Governador Irineu Bornhausen, 3440/204

Agronômica

88025-200 Florianópolis, SC

E-mail: pehelayel@hotmail.com entes, os volumes na abordagem parassacral foram $21,8 \mathrm{~mL}$ para ropivacaína e 20,5 $\mathrm{mL}$ para bupivacaína; e na infraglútea- parabiceptal foram $27,2 \mathrm{~mL}$ na ropivacaína e $25,5 \mathrm{~mL}$ na bupivacaína. O volume efetivo em $99 \%$ dos pacientes no BNI parassacral para ropivacaína foi $24 \mathrm{~mL}$ e para bupivacaína 22,5 $\mathrm{mL}$; e $29,9 \mathrm{~mL}$ de ropivacaína e $28,0 \mathrm{~mL}$ de bupivacaína no grupo infraglúteoparabiceptal.

CONCLUSÕES: Foram necessários volumes significativamente menores na abordagem parassacral do BNI comparativamente à abordagem infraglúteaparabiceptal, mas os volumes anestésicos não diferiram entre os $A L$.

Unitermos: ANESTÉSICO, LOCAL: bupivacaína; ropivacaína; TÉCNICAS ANESTÉSICAS, Regional: bloqueio do nervo isquiático.

\section{SUMMARY}

Helayel PE, Conceição DB, Knaesel JA, Ceccon MS, Dal Mago AJ, Oliveira Filho GR - Effective Anesthetic Volumes in Sciatic Nerve Block: Comparison between the Parasacral and Infragluteal-parabiceps Approaches with $0.5 \%$ Bupivacaine with Adrenaline and 0.5\% Ropivacaine.

BACKGROUND AND OBJECTIVES: The volume and mass of local anesthetics (LA) affect the success rate of peripheral nerve blocks. Thus, the main objective of this study was to determine the volumes of local anesthetics in parasacral and infragluteal-parabiceps sciatic nerve block (SNB).

METHODS: One hundred and one patients undergoing infragluteal-parabiceps or parasacral SNB with $0.5 \%$ ropivacaine or $0.5 \%$ bupivacaine with $5 \mu \mathrm{g} . \mathrm{mL}^{-}$ of adrenaline were randomly divided into 4 groups. Success was defined as complete sensitive and motor blockades of the sciatic nerve 30 minutes after the administration of the LA. Volumes were calculated by the up-and-down method.

RESULTS: In the parasacral approach, the mean effective volume of ropivacaine was $17.6 \mathrm{~mL}$ (95\% Cl: 14.9-20.8) and of bupivacaine it was $16.4 \mathrm{~mL}(95 \%$ Cl: 12.3-21.9). In the infragluteal-parabiceps approach, the mean effective volume of ropivacaine was $21.8 \mathrm{~mL}$ (95\% Cl: 18.7-25.5), and that of bupivacaine was $20.4 \mathrm{~mL}$ (95\% Cl: 18.6-22.5). Volumes were significantly lower $(p<0.01)$ in the parasacral than in the infragluteal-parabiceps approach. In Probit regression, the estimated effective volume in $95 \%$ of the patients in the parasacral approach was $21.8 \mathrm{~mL}$ for ropivacaine, and $20.5 \mathrm{~mL}$ for bupivacaine; in the infragluteal-parabiceps approach the volumes were $27.2 \mathrm{~mL}$ for ropivacaine and $25.5 \mathrm{~mL}$ for bupivacaine. The effective volume in $99 \%$ of the patients in parasacral SNB was $24 \mathrm{~mL}$ for ropivacaine, and $24 \mathrm{~mL}$ for bupivacaine; and in the infragluteal-parabiceps approach, $29.9 \mathrm{~mL}$ for ropivacaine, and $28.0 \mathrm{~mL}$ for bupivacaine.

CONCLUSIONS: In sciatic nerve block, significantly smaller volumes were necessary in the parasacral than in the infragluteal-parabiceps approach, but volumes did not differ between both LAs.

Keywords: ANESTHETIC, Local: bupivacaine, ropivacaine; ANESTHETIC TECHNIQUES, Regional: sciatic nerve block. 


\section{Effective Anesthetic Volumes in Sciatic Nerve Block: Comparison between the Parasacral and Infragluteal-parabiceps Approaches with $0.5 \%$ Bupivacaine with Adrenaline and $0.5 \%$ Ropivacaine}

Pablo Escovedo Helayel, TSA, M.D. 1; Diogo Brüggemann da Conceição, TSA, M.D. ${ }^{2}$; Julian Alexander Knaesel, M.D. ${ }^{3}$; Maurício Sperotto Ceccon, M.D. ${ }^{3}$; Adilson José Dal Mago, TSA, M.D. ${ }^{4}$; Getúlio Rodrigues de Oliveira Filho, TSA, M.D. ${ }^{5}$

\section{INTRODUCTION}

The volume injected as well as the mass of local anesthetics used in peripheral nerve blocks affect the success rate and quality of the blockade ${ }^{1,2}$. Sciatic nerve blocks require relatively larger volumes of local anesthetics ${ }^{3-5}$. Those volumes vary according to the approach and can be relevant when limit doses are achieved ${ }^{6}$. The minimum local anesthetic volume (MLAV) is the mean effective volume to produce complete neural blockade in $50 \%$ of the patients ${ }^{1,7,8}$. Analogue to the dose of the drug that is effective in $50 \%$ of a specific population (ED50), MLAV is located in the middle of the dose (volume)-response curve, which is more easily affected by the differences among drugs. The concept of MLAV can also guide the needs of local anesthetics in different injection sites. Ropivacaine and bupivacaine are local anesthetics frequently used in sciatic nerve blocks; however, studies comparing these drugs have used fixed volumes and concentrations $^{9,10}$. Volumes of local anesthetics effective in $50 \%, 95 \%$, and $99 \%$ of the patients can vary among the different techniques and/or different anesthetic solutions; therefore, their determination is clinically relevant. The main objective of this study was to estimate the minimum effective volumes in sciatic nerve blocks in 50\%, 95\% and $99 \%$ of the cases using the parasacral or infragluteal-parabiceps approach. The secondary goal was to compare the effective volumes in $50 \%, 95 \%$, and $99 \%$ of the most commonly used local anesthetics ( $0.5 \%$ ropivacaine and $0.5 \%$ bupivacaine with 1:200,000 adrenaline).

\section{METHODS}

After approval by the Ethics on Research Committee of the Hospital Governador Celso Ramos, 101 patients physical status ASA I or II, ages 18 to 65 years, scheduled for elective foot or ankle surgery under femoral and sciatic blocks participated in this prospective study. Patients with respiratory, hepatic, or cardiac dysfunction; diabetics; peripheral neuropathy; in chronic analgesic therapy; or allergies to the study drugs were excluded from the study.

Patients were randomly divided into four groups according to electronically generated numbers. RIG group $(n=25)$ : patients undergoing infragluteal-parabiceps sciatic nerve block (SNB) with $0.5 \%$ ropivacaine; BIG group $(n=25)$ : infragluteal-parabiceps SNB with $0.5 \%$ bupivacaine with $1: 200,000$ adrenaline; RPS group $(n=25)$, parasacral SNB with $0.5 \%$ ropivacaine; and BPS group $(n=26)$, parasacral SNB with $0.5 \%$ bupivacaine with 1:200,000 adrenaline. After venipuncture with a flexible catheter in the forearm all patients received pre-anesthetic medication with midazolam, $0.05 \mathrm{mg} \cdot \mathrm{kg}^{-1} 10$ minutes before the blockade. Syringes containing the local anesthetic were prepared in a doubleblind manner by one of the authors who was not involved in the evaluation of the patient. All blockades were done at least 45 minutes before the beginning of the surgery by one of the investigators highly experienced in regional blocks who did not know which anesthetic was being used. Patients were placed in ventral decubitus with their legs supported by a pillow, allowing them to move their feet freely in response to peripheral nerve stimulation. For the infragluteal-parabiceps $\mathrm{SNB}$, the needle was inserted $1 \mathrm{~cm}$ distal to the infragluteal fold at the level of the lateral border of the femoral biceps muscle. The skin was infiltrated with $2 \mathrm{~mL}$ of $1 \%$ lidocaine with a 25G, 38-mm needle. A 50-mm, 22G peripheral nerve stimulation needle (Stimuplex A50, BBraun, Melsungen, Germany) connected the neurostimulator (Stimuplex Dig RC, BBraun, Melsungen, Germany) was inserted at a $70^{\circ}$ to $80^{\circ}$ angle with the skin, in a cephalad and anterior direction to the sagittal plane ${ }^{11}$. Both plantar flexion of the foot or toes (tibial branch of the sciatic nerve) and dorsiflexion/eversion of the foot or toes (common fibular division of the sciatic nerve) were obtained with neurostimulation currents of 0.2 to $0.5 \mathrm{~mA}$ and pulse of $100 \mu \mathrm{s}$. The double injection technique was used. The volume of the local anesthetic used was equally divided between the tibial and common fibular nerves, direct branches of the sciatic nerve. The patient was excluded from the study if it was impossible to determine one of the stimuli or if the time necessary to find the second stimulus was greater than three minutes after the first injection of local anesthetic. The end of the administration of the anesthetic in the second injection site was considered moment zero for the evaluation of the blockade effectivity.

For the parasacral SNB, a line was drawn from the posterior superior iliac spine (PSIS) to the ischial tuberosity (IT); the needle was inserted $6 \mathrm{~cm}$ caudal to the PSIS ${ }^{12,13}$. After 
infiltrating the skin with $2 \mathrm{~mL}$ of $1 \%$ lidocaine with a $38-\mathrm{mm}$, $25 \mathrm{G}$ needle, a $100-\mathrm{mm}, 21 \mathrm{G}$ peripheral neurostimulation needle (Stimuplex A100, BBraun, Melsungen, Germany) connected to the same neurostimulator (Stimuplex Dig, EC, BBraun, Melsungen, Germany) was inserted in the sagittal plane with a subtle caudal angulation $\left(10^{\circ}\right)$. The needle reached the greater sciatic foramen until the sciatic nerve, which was identified by a stimulus of plantar flexion of the foot or toes (tibial branch of the sciatic nerve) and dorsiflexion/ eversion of the foot or toes (common fibular branch of the sciatic nerve) with a neurostimulation current between 0.2 and $0.5 \mathrm{~mA}$ and pulse of $100 \mu \mathrm{s}$ and a single injection was administered. The end of the injection of the local anesthetic was considered moment zero for the evaluation of the effectivity of the blockade.

After the SNB, the patient returned to the supine position for the inguinal paravascular femoral nerve block $(1 \mathrm{~cm}$ lateral to the femoral artery and $1 \mathrm{~cm}$ below to the inguinal ligament) with the same needle used for the sciatic nerve block and 15 $\mathrm{mL}$ of the same local anesthetic solution.

An observer who was not present during the nerve block and who did not know which local anesthetic and volume were used evaluated the effectivity of the blockade. The sensitive blockade was evaluated by the loss of sensitivity to pin prick on a three-point scale $(0=$ normal, painful feeling; $1=$ reduction in sensitivity, but with tactile feeling; $2=$ complete loss of sensitivity in the area) in the region of cutaneous innervation corresponding to the common fibular nerve (dorsal aspect of the foot), as well as that of the tibial nerve (sole of the foot). The motor blockade was evaluated by plantar flexion (tibial nerve) or dorsiflexion of the foot (fibular nerve), according to a three-point scale $(0=$ normal movement; 1 = reduced movement, paresia; 2 = absence of movement). A total score of effectivity was attributed to each blockade by adding the scores of the sensitive and motor evaluations in each component of the sciatic nerve. The score ranged from zero (absence of sensory and motor blockade) to eight (complete sensory and motor blockades in both territories of the sciatic nerve). Success was defined as a total effectivity score of eight after $\mathbf{3 0}$ minutes and lower scores were considered failure.

Twenty milliliters of the local anesthetic solution was administered in the first patient of each group. The response of the patient 30 minutes after the injection determined the volume to be administered to the next patient. Success or failure determined the increase or reduction in the volume of the local anesthetic administered to the next patient. To calculate the interval between sequentially administered volumes, the initial volume was transformed into its natural logarithm ${ }^{14,15}$. Adding or subtracting 0.1 to the normalized result of the prior patient determined the result to be calculated for the next patient. The volumes injected were obtained by transforming the calculated volumes into their respective anti-logarithms approximated to one decimal.
Fractional doses of midazolam $\left(0.05 \mathrm{mg} \cdot \mathrm{kg}^{-1}\right)$ or continuous infusion of propofol (50 to $70 \mu \mathrm{g} \cdot \mathrm{kg}^{-1} \cdot \mathrm{min}$ ) were used for intraoperative sedation. General anesthesia was used when the sensory blockade was not enough to perform the surgery under sedation.

The sample size necessary to achieve an estimated standard error for the effective volume in $50 \%$ of the patients $\left(\delta_{x}\right)$ equal to $0.3 \delta$ (standard deviation of the effective volume in $50 \%$ of the patients) of the up-and-down sequences was calculated as $n=2\left(\delta / \delta_{x}\right)^{2}$, resulting in 22 patients per group ${ }^{15}$. The sample size for Probit analysis was estimated in at least 44 pairs of success/failures, for $\alpha=0.5$ and $1-\beta=0.8$, using Kramer and Shimura ${ }^{16}$ formulas and tables for binominal tests for simple samples. The mean effective volume of ropivacaine and bupivacaine in parasacral and infraglutealparabiceps SNB were estimated from the respective up-anddown sequences using the Massey and Dixon method focused on the determination of the volume of local anesthetic with a $50 \%$ probability of a complete nerve block. Probit analysis was applied to the data using local anesthetic solutions and blockade technique (approaches). From these analysis, the effective volumes in $95 \%$ and $99 \%$ of the patients were estimated for the local anesthetics (bupivacaine and ropivacaine) and their approaches (parasacral and infragluteal-parabiceps). The Robertson and Preisler ${ }^{17}$ method was used to calculate the rates of effective volumes in $50 \%, 95 \%$, and $99 \%$ of the patients (ropivacaine/bupivacaine and parasacral/infragluteal-parabiceps) and the respective $95 \%$ confidence interval. According to this method if $95 \%$ of the confidence interval of the rates include 1 the estimated differences were not statistically significant in $\alpha=$ 0.05. Microsoft Excel 2000 (Microsoft, Bellvue, WA) and Minitab v. 1.2 (Minitab Inc., State College, PA) were used for the calculations.

\section{RESULTS}

Ninety-nine patients completed the study. The demographic data can be summarized as follows: Age $=36.72 \pm 12.86$ years; Weight $=71.69 \pm 12.28$; Height $=1.67 \pm 0.10$; Gender $\mathrm{M} / \mathrm{F}=54 / 45 ;$ Physical status ASA $\mathrm{I} / \mathrm{II}=47 / 72$.

Figures 1 and 2 show the sequence of effective (successes) and ineffective (failures) blockades in the four study groups. Forty-eight failures and 51 successes were observed. In parasacral SNB, ropivacaine had a mean effective volume of $17.6 \mathrm{~mL}$ (95\% Cl: $14.9-20.8)$, and bupivacaine $16.4 \mathrm{~mL}(95 \% \mathrm{Cl}$ : 12.3-21.9) as promoting complete blockade in $50 \%$ of the cases. In infragluteal-parabiceps SNB, the corresponding volumes were of $21.8 \mathrm{~mL}$ for ropivacaine $(95 \% \mathrm{Cl}$ : $18.7-25.5)$ and $20.4 \mathrm{~mL}(95 \% \mathrm{Cl}: 18.6-22.5)$ for bupivacaine. Table I summarizes the effective volumes in $50 \%, 95 \%$, and $99 \%$ of the cases estimated by Probit regression for the anesthetic solutions, as well as their approaches. The result of the Chisquare test for the general model was $5.14 ; p=0.64$. 

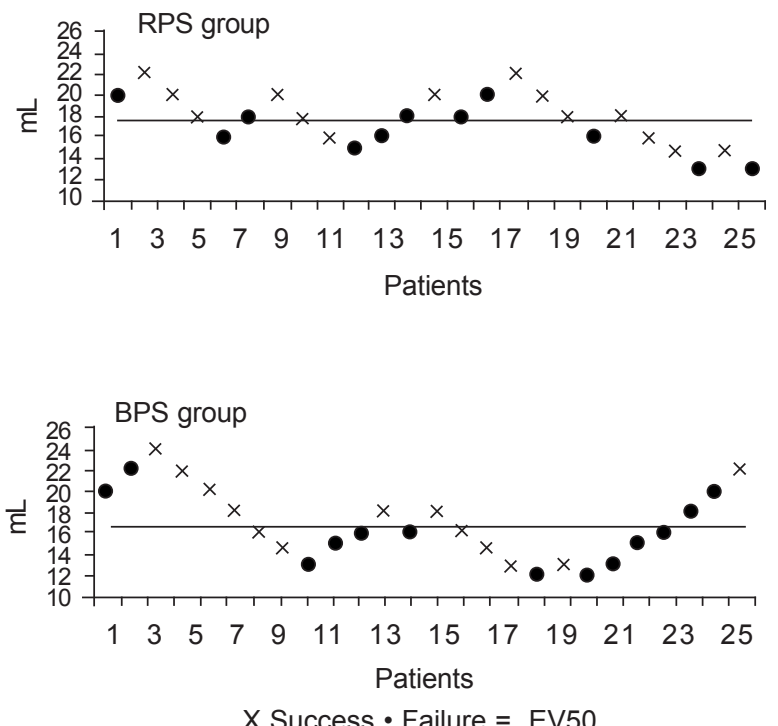

Figure 1. Sequence of Responses of Patients and Respective EV50 Calculated by the Up-and-down Method in Parasacral SNB with $0.5 \%$ Ropivacaine (RPS) or $0.5 \%$ Bupivacaine (BPS).
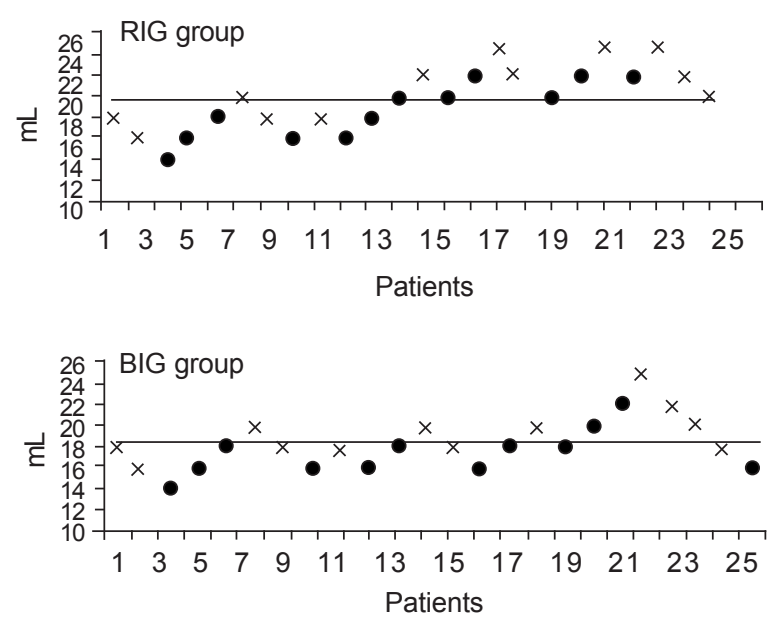

$\mathrm{X}$ Success $\cdot$ Failure $=\mathrm{EV} 50$

Figure 2. Sequence of Response of Patients and Respective EV50 Calculated by the Up-and-down Method in the InfraglutealParabiceps SNB with $0.5 \%$ Ropivacaine (RIG) or $0.5 \%$ Bupivacaine (BIG).

Fifty-one patients underwent parasacral SNB. Fourteen patients (56\%) in the RPS group and $13(50 \%)$ in the BPS group achieved complete blockade after 30 minutes. Surgical procedures were completed successfully in all pa-
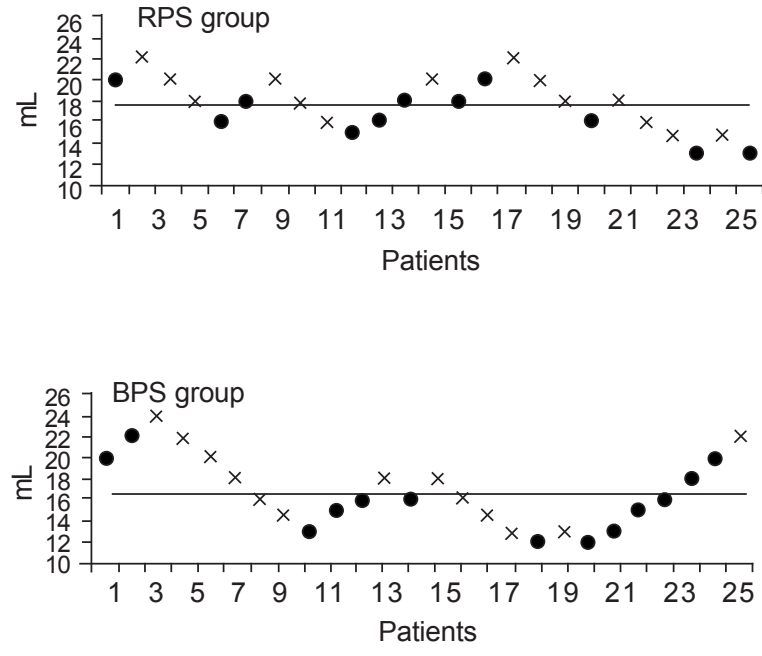

X Success $\cdot$ Failure $=$ EV50

Figura 3. Sequence of responses of patients and respective EV50 calculated by the up-and-down method in parasacral SNB with $0.5 \%$ ropivacaine $(R I G)$ or $0.5 \%$ bupivacaine $(B I G)$
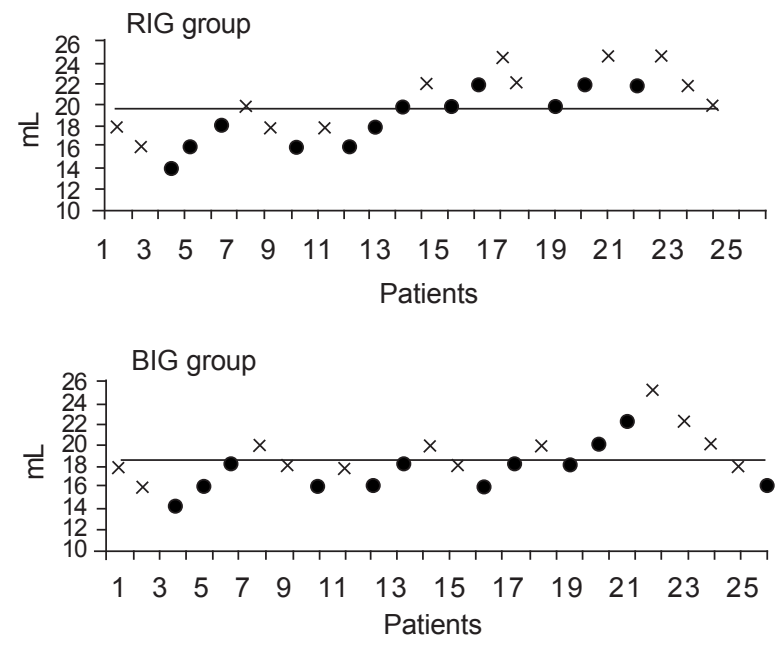

X Success $\cdot$ Failure $=$ EV50

Figure 4. Sequence of responses of patients and respective EV50 calculated by the up-and-down method in infraglutealparabiceps SNB with $0.5 \%$ ropivacaine (RIG) or $0.5 \%$ bupivacaine (BIG)

tients undergoing combined parasacral sciatic and femoral nerve blocks.

In two of 50 patients who underwent infragluteal-parabiceps SNB (one patient in the BIG group and one in the RIG group) 
Table I - Effective Volumes of 0.5\% Ropivacaine and 0.5\% Bupivacaine Calculated by Probit Regression

\begin{tabular}{lcccc}
\hline Groups & RPS & BPS & RIG & BIG \\
\hline EV50 & $17.4(16.6 ; 18.3)^{*}$ & $16.4(15.6 ; 17.2)^{*}$ & $21.7(20.7 ; 22.9)$ & $20.3(19.3 ; 21.4)$ \\
EV95 & $21.8(20.6 ; 23.4)$ & $20.5(19.4 ; 22.0)$ & $27.2(25.7 ; 29.4)$ & $25.5(24.0 ; 27.4)$ \\
EV99 & $24.0(22.5 ; 26.1)$ & $22.5(21.1 ; 24.5)$ & $29.9(27.9 ; 32.7)$ & $28.0(26.1 ; 30.5)$ \\
\hline
\end{tabular}

EV50, EV95, EV99 - Estimated effective volumes for successful blockade in 50\%, 95\%, and 99\% of the cases, respectively. The numbers in parenthesis represent the 95\% confidence intervals. RPS = parasacral SNB with $0.5 \%$ ropivacaine; BPS $=$ parasacral SNB with $0.5 \%$ bupivacaine; RIG = infragluteal-parabiceps SNB with $0.5 \%$ ropivacaine; BIG = infragluteal-parabiceps SNB with $0.5 \%$ bupivacaine.

Comparison between RIG and BIG groups $=p<0.05$

the second stimulus was not possible because immediately after the first injection of local anesthetic both components of the sciatic nerve were blocked. Those patients were excluded from the study, and their volumes and anesthetic solutions were administered to the subsequent patients. In the 48 remaining patients, 12 patients in the RIG group $(50 \%)$, as well as 12 patients in the BIG group $(50 \%)$, achieved complete sciatic nerve block after 30 minutes. Only one patient required general anesthesia to complete the surgery. The procedures were completed successfully in 47 patients who underwent infragluteal-parabiceps SNB combined with femoral nerve block. The interval between the identification of both stimuli was below three minutes in all patients in the RIG and BIG groups.

\section{DISCUSSION}

The sciatic nerve is the largest nerve in the body. The larger branches of the sciatic nerve come out of the greater sciatic foramen covered by a common epineural sheath and by the sacral compartment fascia ${ }^{18}$. The nerve divides into its largest terminal branches, the tibial and common fibular nerves, at the level of or distal to the piriformis muscle. In the infragluteal region, both branches are separated from each other, but they are still within one common epineural sheath ${ }^{19}$. Due to this anatomical characteristic, the parasacral approach is frequently successful and the local anesthetic has a predictable dispersion through the sheath of the sciatic nerve with a single injection of a relatively small volume through the sacral compartment fascia ${ }^{12}$. However, in the infraglutealparabiceps approach, double injection guarantees faster onset of action and better quality of the neural blockade in both terminations of the sciatic nerve, allowing greater proximity of the injection to its site of action ${ }^{4,5,20,21}$. Besides, it has been demonstrated that when the sciatic nerve is approached below the piriformis muscle the double-injection technique is necessary to obtain success rates similar to that of the parasacral approach with a single injection ${ }^{5}$. For this reason, we used the double injection in the infragluteal-parabiceps approach of the sciatic nerve.

The intra-epineural administration of the local anesthetic can explain the complete neural blockade observed in two patients who underwent infragluteal-parabiceps SNB immediately after the first injection with half of the pre-established volume of local anesthetic.

The up-and-down method of Massey and Dixon has been used to calculate the volume, dose, or concentration of local anesthetic in $50 \%$ of the cases ${ }^{1,22}$. The need of a smaller study population, when compared with randomized methods, and the reduction in the incidence of failures represent the greatest advantages of this method ${ }^{15,23}$. However, it does not estimate the volumes of local anesthetics necessary to promote anesthesia in $95 \%$ and $99 \%$ of the patients, which would be clinically more relevant ${ }^{23}$. For this reason, Probit regression was used to calculate the estimated volumes of anesthetic effective in $95 \%$ and $99 \%$ of the patients ${ }^{24}$. Both methods use normal distribution to estimate the effective volumes. Methods that use normal distribution in a wide margin cannot be used to calculate extreme percentages, since those estimates require the assumption that the phenomenon has normal distribution. Logarithm transformation, such as the one used in the present study, can promote normal parameters in relation to the mean, but it fails to assume normalcy in extreme ranges of distribution ${ }^{15}$. Narrow confidence intervals for effective volumes in $95 \%$ and $99 \%$ of the patients can reflect this limitation. In fact, an extensive study on distribution involving hundreds of observations would be necessary to guarantee normalcy in narrow ranges ${ }^{14}$, which is not feasible in most clinical research centers.

Success was defined as complete neural blockade of the tibial and common fibular components of the sciatic nerve. This criterion revealed to be too strict since, to allow the surgery on the area of sciatic innervation, only one patient required general anesthesia to complete the surgery, even in the face of incomplete motor blockade. In the present study, it was decided to compare the effective volume of two local anesthetics frequently used, i.e., $0.5 \%$ ropivacaine and $0.5 \%$ bupivacaine with 1:200,000 epinephrine. Due to the addition of epinephrine to bupivacaine, the potency of both drugs was not compared.

We concluded that the effective volumes of local anesthetics in $50 \%$ of the cases were significantly lower for the single in 19. Vloka JD, Hadzic A, Lesser JB et al. - A common epineural sheath for the nerves in the popliteal fossa and its possible implications 
jection in the parasacral approach than in the double injection in infragluteal-parabiceps SNB. A difference in predicted volumes associated with the probability of a blockade in $95 \%$ and $99 \%$ of the cases after 30 minutes was not observed. Besides, in the same approach, similar volumes of $0.5 \%$ ropivacaine and $0.5 \%$ bupivacaine with $1: 200,000$ adrenaline were necessary for successful sciatic nerve block.

\section{REFERÊNCIAS - REFERENCES}

01. Casati A, Fanelli G, Magistris L et al. - Minimum local anesthetic volume blocking the femoral nerve in $50 \%$ of cases: a doubleblinded comparison between $0.5 \%$ ropivacaine and $0.5 \%$ bupivacaine. Anesth Analg, 2001;92:205-208.

02. Vester-Andersen T, Husum B, Lindeburg $T$ et al. - Perivascular axillary block IV: blockade following 40,50 or $60 \mathrm{ml}$ of mepivacaine $1 \%$ with adrenaline. Acta Anaesthesiol Scand 1984;28:99-105.

03. Morris GF, Lang SA, Dust WN et al. - The parasacral sciatic nerve block. Reg Anesth, 1997;22:223-228.

04. Taboada M, Alvarez J, Cortes J et al. - Is a double-injection technique superior to a single injection in posterior subgluteal sciatic nerve block? Acta Anaesthesiol Scand, 2004;48:883-887.

05. Cuvillon P, Ripart J, Jeannes $P$ et al. - Comparison of the parasacral approach and the posterior approach, with single and double-injection techniques, to block the sciatic nerve. Anesthesiology, 2003;98:1436-1441.

06. Rosenberg PH, Veering BT, Urmey WF - Maximum recommended doses of local anesthetics: a multifactorial concept. Reg Anesth Pain Med, 2004;29:564-575.

07. Helayel PE, Lobo G, Vergara R et al. - Volumes efetivos de anestésicos locais para o bloqueio do compartimento da fáscia ilíaca: Estudo comparativo duplamente encoberto entre ropivacaína a 0,5\% e bupivacaína a 0,5\%. Rev Bras Anestesiol, 2006; 56:454460 .

08. Soares LF, Barros ACM, Almeida GP et al. - Volume anestésico mínimo para o bloqueio retrobulbar extraconal: comparação entre soluções a $0,5 \%$ de bupivacaína racêmica de levobupivacaína e da mistura enantiomérica S75/R25 de bupivacaína. Rev Bras Anestesiol, 2005;55:263-268.

09. Casati A, Borghi B, Fanelli G et al. - A double-blinded, randomized comparison of either $0.5 \%$ levobupivacaine or $0.5 \%$ ropivacaine for sciatic nerve block. Anesth Analg, 2002;94:987-990.

10. Fanelli G, Casati A, Beccaria P et al. - A double-blind comparison of ropivacaine, bupivacaine, and mepivacaine during sciatic and femoral nerve blockade. Anesth Analg, 1998;87:597-600.

11. Sukhani R, Candido KD, Doty $R$ et al. - Infragluteal-parabiceps sciatic nerve block: an evaluation of a novel approach using a single-injection technique. Anesth Analg, 2003;96:868-873.

12. Gaertner $E$, Lascurain $P$, Venet $C$ et al. - Continuous parasacral sciatic block: a radiographic study. Anesth Analg 2004; 98:831834.

13. Mansour NY - Reevaluating the sciatic nerve block: another landmark for consideration. Reg Anesth, 1993;18:322-323.

14. Dixon WJ, Massey F - Introduction to Statistical Analysis, $4^{\text {th }} \mathrm{Ed}$, New York, McGraw Hill, 1983.

15. Dixon WJ - Staircase bioassay: the up-and-down method. Neurosci Biobehav Rev, 1991;15:47-50.

16. Kraemer HC, Thiemann S - How Many Subjects? Statistical power analysis in research. Newbury Park, SAGE, 1987.

17. Robertson JL, Preisler HK - Pesticides Bioassays with Arthropods. Boca Raton, CRC Press, 1992.

18. de Visme V, Picart F, Le Jouan R et al. - Combined lumbar and for sciatic nerve block. Anesth Analg, 1997;84:387-390.

20. Fanelli G, Casati A, Garancini P et al. - Nerve stimulator and multiple injection technique for upper and lower limb blockade: failure rate, patient acceptance, and neurologic complications. Study Group on Regional Anesthesia. Anesth Analg, 1999;88:847-852.

21. Bailey SL, Parkinson SK, Little WL et al. - Sciatic nerve block. A comparison of single versus double injection technique. Reg Anesth, 1994;19:9-13.

22. Capogna G, Celleno D, Fusco P et al. - Relative potencies of bupivacaine and ropivacaine for analgesia in labour. $\mathrm{Br} \mathrm{J}$ Anaesth, 1999;82:371-373.

23. Lichtman $\mathrm{AH}$ - The up-and-down method substantially reduces the number of animals required to determine antinociceptive ED50 values. J Pharmacol Toxicol Methods, 1998;40:81-85.

24. Lacassie HJ, Columb MO, Lacassie HP et al. - The relative motor blocking potencies of epidural bupivacaine and ropivacaine in labor. Anesth Analg, 2002;95:204-208.

\section{RESUMEN}

Helayel PE, Conceição DB, Knaesel JA, Ceccon MS, Dal Mago AJ, Oliveira Filho GR - Volúmenes Anestésicos Efectivos en el Bloqueo del Nervio Isquiático: comparación entre los Abordajes Parasacral e Infraglúteo-Parabicipital con Bupivacaína a $0,5 \%$ con Adrenalina y Ropivacaína a 0,5\%.

JUSTIFICATIVA Y OBJETIVOS: El volumen y la masa de las soluciones de anestésico local ( $A L)$, influyen en la tasa de éxito de los bloqueos periféricos. Así, el objetivo principal del estudio fue determinar los volúmenes de anestésico local para el bloqueo del nervio isquiático (BNI) en los abordajes parasacral e infraglúteoparabicipital.

MÉTODO: Ciento y un pacientes se ubicaron aleatoriamente en 4 grupos y fueron sometidos al BNI para los abordajes infraglúteoparabicipital o parasacral, utilizando ropivacaína a 0,5\% o bupivacaína a $0,5 \%$ con adrenalina $5 \mu \mathrm{g} \cdot \mathrm{mL}^{-1}$. El éxito se definió como bloqueo sensitivo y motor completo del nervio isquiático 30 minutos después de la inyección del AL. Los volúmenes se calcularon a través del método up-and-down.

RESULTADOS: En el abordaje parasacral, el volumen efectivo promedio de la ropivacaína fue de 17,6 mL (IC 95\%: 14,9 - 20,8) y el de la bupivacaína 16,4 mL (IC 95\%: 12,3 - 21,9). En el abordaje infraglúteo-parabicipital el volumen efectivo promedio de la ropivacaína fue $21,8 \mathrm{~mL}$ (IC 95\%: 18,7 - 25,5) y bupivacaína 20,4 mL (IC 95\%: 18,6 - 22,5). Los volúmenes fueron significativamente menores $(p<0,01)$ en el abordaje parasacral al compararlos con el infraglúteo-parabicipital. En la estimativa de la regresión de Probits para volúmenes efectivos en un $95 \%$ de los pacientes, los volúmenes en el abordaje parasacral fueron 21,8 mL para la ropivacaína y 20,5 mL para la bupivacaína; y en el infraglúteo-parabicipital fueron $27,2 \mathrm{~mL}$ en la ropivacaína y $25,5 \mathrm{~mL}$ en la bupivacaína. El volumen efectivo en un $99 \%$ de los pacientes, en el BNI parasacral, para la ropivacaína fue $24 \mathrm{~mL}$ y para la bupivacaína $22,5 \mathrm{~mL}$; y 29,9 $m L$ de ropivacaína y $28,0 \mathrm{~mL}$ de bupivacaína en el grupo infraglúteoparabicipital.

CONCLUSIONES: Se hicieron necesarios volúmenes significativamente menores en el abordaje parasacral del BNI al compararlos con el abordaje infraglúteo-parabicipital, pero los volúmenes anestésicos no fueron diferentes entre los $A L$. 